\title{
ANALISIS PELAKSANAAN PERATURAN BUPATI MERANGIN NOMOR 7O TAHUN 2018 TENTANG TAMBAHAN PENGHASILAN KARYAWAN DALAM PENINGKATAN DISIPLIN DINAS PNS DI DINAS PEKERJAAN PUBLIK DAN TATA RUANG KABUPATEN MERANGIN
}

\author{
Farid Hidayat ${ }^{1}$
}

\author{
${ }^{1}$ Program Pasca Sarjana \\ Universitas Terbuka \\ sultanfarid73@yahoo.com
}

Received : 19 April 2021

Revised : 07 May 2021

Accepted : 17 June 2021

Published : 21 June 2021

\section{ABSTRACT}

This study aims to analyze and determine the implementation of additional employee income in the Department of Public Works and Spatial Planning, Merangin Regency. Researchers used a qualitative approach to collecting data. The informants in this study were employees of the Merangin District Public Works and Spatial Planning Service with informants consisting of 10 persons. To obtain data or information needed accurately in this study, researchers used in-depth interviews. The technique of collecting data by interview is done by giving questions - direct questions orally, the goal is to obtain primary data from informants. Furthermore, using the literature study method, namely data collection techniques that are relevant to research problems, such as through books, newspapers, or other supporting literature. The results show that since the enactment of Merangin Regent Regulation Number 70 of 2018 concerning the provision of Additional Employee Income, there has been a very good discipline increase. From the explanation above, the writer suggests that the TPP given to employees needs to be evaluated by the amount given, so that not only the discipline becomes good but the enthusiasm for work will certainly increase. So that the work that has been previously planned can be carried out and what is the vision and mission of the organization can be carried out properly.

Keywords: implementation; additional income; employee; discipline

\section{ABSTRAK \\ Penelitian ini bertujuan untuk menganalisis dan mengetahui penerepan penambahan pendapatan pegawai pada Dinas Pekerjaan Umum dan Penataan Ruang Kabupaten Merangin. Peneliti menggunakan pendekatan kualitatif untuk mengumpulkan data. Informan dalam penelitian ini adalah pegawai Dinas Pekerjaan Umum dan Penataan Ruang Kabupaten Merangin, 10 orang. Untuk memperoleh data atau informasi yang dibutuhkan secara akurat dalam penelitian ini, peneliti menggunakan wawancara mendalam. Teknik pengumpulan data dengan wawancara dilakukan dengan cara memberikan pertanyaan - pertanyaan langsung secara lisan untuk memperoleh data primer dari informan. Selanjutnya menggunakan metode studi kepustakaan, yaitu teknik pengumpulan data yang relevan dengan masalah penelitian, seperti melalui buku, surat kabar, atau literatur pendukung lainnya. Hasil penelitian menunjukkan bahwa sejak berlakunya Peraturan Bupati Merangin Nomor 70 Tahun 2018 tentang Pemberian Tambahan Penghasilan Pegawai, terjadi peningkatan disiplin yang luar biasa. Dari penjelasan tersebut penulis menyarankan agar TPP yang diberikan kepada karyawan perlu dievaluasi dengan besaran yang diberikan. Disiplin menjadi baik, tetapi semangat kerja pasti akan meningkat. Sehingga pekerjaan yang telah direncanakan sebelumnya dapat terlaksana dan visi misi organisasi dapat terlaksana dengan baik.}

Kata Kunci: penerapan; tambahan penghasilan; pekerja; disiplin 


\section{Pendahuluan}

Terselenggarannya pemerintahan yang baik dapat diwujudkan melalui sistem dan aparatur yang memiliki kinerja baik. Kelancaran penyelenggaraan tugas pemerintah daerah sangat tergantung kepada ke sempurnaan Aparatur Negara, khususnya Pegawai Negeri Sipil (PNS) yang bertransformasi menjadi Aparatur Sipil Negara (ASN). Instansi pemerintah di tuntut untuk menciptakan kinerja aparatur pemerintahan yang tinggi guna pengembangan pelayanan publik. Pemerintah Daerah harus mampu membangun dan meningkatkan kinerja dalam lingkungannya, untuk itu Pemerintah Daerah dituntut dapat meningkatkan kapasitas sumber daya manusia karena sumber daya manusia merupakan pelaku pelayanan, Sebagai pelayanan masyarakat aparatur di tuntut untuk memberikan pelayanan sebaik baiknya menuju good governance, sehingga dapat memberikan pelayanan publik dengan baik. Dalam Peraturan Pemerintah Republik Indonesia Nomor 53 Tahun 2010 tentang Disiplin Pegawai Negeri Sipil, dalam Bab I tentang kewajiban, menyebutkan bahwa Aparatur Sipil Negara, wajib memberikan pelayanan sebaik-baiknya kepada masyarakat, masuk kerja dan mentaati ketentuan jam kerja, mencapai sasaran kerja pegawai yang ditetapkan, mengunakan dan memelihara barang-barang milik Negara dengan sebaik baiknya.

Banyak faktor yang mempengaruhi prestasi, namun yang akan dilihat pengaruhnya terhadap prestasi kerja pada penelitian ini adalah tambahan penghasilan pegawai dalam meningkatkan disiplin, dan kualitas dalam pelayanan terhadap masyarakat. Salah satunya adalah Tambahan Penghasilan Pegawai (TPP) yang merupakan insentif bagi para Pegawai Negeri Sipil daerah.

Pemberian Tambahan Penghasilan ini berdasarkan ketentuan Pasal 39 ayat (1) dan ayat (8) Peraturan Menteri Dalam Negeri Nomor 13 Tahun 2006 tentang pedoman pengelolaan keuangan daerah sebagaimana telah diubah terakhir dengan Peraturan Menteri Dalam Negeri Nomor 21 Tahun 2011 tentang Pedoman Pengelolaan Keuangan Daerah, Pemberian Tambahan Penghasilan dilaksanakan dengan memperhatikan kemampuan keuangan daerah dan ditetapkan dengan Peraturan Kepala Daerah.

Pada Pemerintah Kabupaten Merangin, realisasi Peraturan Menteri Dalam Negeri tersebut diimplementasikan melalui Peraturan Bupati Merangin Nomor 70 Tahun 2018 yang mengatur tentang Tambahan Penghasilan Pegawai Negeri Sipil (TPP) di lingkungan Pemerintah Kabupaten Merangin yang besarannya di sesuaikan dengan kemampuan Daerah.

Tambahan Penghasilan Pegawai (TPP) adalah suatu bentuk penghargaan oleh pemerintah daerah untuk memotivasi dan mendorong Pegawai Negeri Sipil dan Calon Pegawai Negeri Sipil yang bertujuan untuk meningkatkan disiplin, mendorong pegawai untuk meningkatkan prestasi dan kualitas dalam memberikan pelayanan kepada masyarakat, meningkatkan kesejahteraan pegawai dan meningkatkan kinerja pegawai.

Meningkatkan disiplin menurut Peraturan Bupati Merangin Nomor 70 tahun 2018 ini adalah kesanggupan Pegawai Negeri Sipil (PNS) dan Calon Pegawai Negeri Sipil (CPNS) untuk mentaati kewajiban dan menghindari larangan yang ditentukan dalam peraturan perundang undangan dan/atau peraturan kedinasan yang apabila tidak di taati atau dilanggar di jatuhi hukuman disiplin.

Dalam Peraturan Bupati ini Pegawai Negeri Sipil di wajibkan membuat laporan harian pelaksanaan tugas pegawai yang isinya terdiri dari Laporan kinerja harian PNS/CPNS yang di buat berdasarkan Sasaran Kerja Pegawai (SKP) dan/atau tugas lainnya yang di berikan atasan. SKP ini adalah Rencana Kerja dan target yang akan dicapai oleh seorang PNS dan CPNS.

Semenjak diberlakukannya Peraturan Bupati Nomor 70 tahun 2018 tentang Tambahan Penghasilan Pegawai Negeri Sipil (TPP) memberikan warna lain dan perubahan secara signifikan terhadap tingkat disiplin Aparatur Sipil Negara di Lingkup Dinas Pekerjaan Umum dan Penataan Ruang Kabupaten merangin. Menegakkan disiplin kerja sangat penting bagi peningkatan pelayanan publik. Adanya disiplin kerja akan menjamin terpeliharanya tata tertib dan kelancaran pelaksanaan kerja di OPD (Organisasi Perangkat Daerah), sehingga memperoleh hasil yang optimal. Sedangkan bagi Pegawai, disiplin kerja memberikan dampak suasana kerja yang menyenangkan sehingga akan menambah semangat dalam melaksanakan pekerjaannya untuk mencapai tujuan organisasi. Teori yang mendukung penelitian 
Analisis Pelaksanaan Peraturan Bupati Merangin Nomor 70 Tahun 2018 Tentang Tambahan Penghasilan Karyawan dalam Peningkatan Disiplin Dinas PNS di Dinas Pekerjaan Publik dan Tata Ruang Kabupaten Merangin Farid Hidayat

adalah teori implementasi menurut Ripley dan Franklin (1986), implementasi adalah apa yang terjadi sesudah undang-undang di tetapkan yang memberikan otoritas program, kebijakan, keuntungan (benefit), atau suatu jenis keluaran yang nyata (tangible output). Istilah implementasi menuju pada sejumlah kebijakan yang mengikuti pernyataan maksud tentang tujuan-tujuan program dan hasil yang diinginkan oleh pejabat pemerintah. Implementasi mencakup tindakan-tindakan oleh berbagai aktor yang dimaksudkan untuk membuat program berjalan.

Kriteria pengukuran keberhasilan implementasi menurut Ripley dan Franklin (1986: 12) didasarkan pada tiga aspek, yaitu:

a. Tingkat kepatuhan birokrasi terhadap birokrasi di atasnya atau tingkatan birokrasi sebagaimana diatur dalam undang-undang.

b. Adanya kelancaran rutinitas dan tidak adanya masalah.

c. Pelaksanaan dan dampak (manfaat) yang dikehendaki dari semua program yang ada terarah.

Ripley memperkenalkan pendekatan "kepatuhan" dan pendekatan "faktual" dalam implementasi kebijakan (Ripley \& Franklin, 1986: 11). Pendekatan kepatuhan muncul dalam literatur administrasi publik. Pendekatan ini memusatkan perhatian pada tingkat kepatuhan agen atau individu bawahan terhadap agen atau individu atasan. Perspektif kepatuhan merupakan analisis karakter dan kualitas perilaku organisasi. Menurut Ripley, paling tidak terdapat dua kekurangan perspektif kepatuhan, yakni: (1) banyak faktor non-birokratis yang berpengaruh tetapi justru kurang diperhatikan, dan (2) adanya program yang tidak didesain dengan baik. Perspektif kedua adalah perspektif faktual yang berasumsi bahwa terdapat banyak faktor yang mempengaruhi proses implementasi kebijakan yang mengharuskan implementor agar lebih leluasa mengadakan penyesuaian.

Potensi setiap sumber daya manusia yang ada dalam suatu organisasi harus dapat dimanfaatkan dengan sebaik-baiknya sehingga mampu memberikan output yang optimal. Tercapainya tujuan organisasi tidak hanya tergantung pada peralatan modern, sarana dan prasarana yang lengkap, tetapi justru lebih tergantung pada manusia yang melaksanakan pekerjaan tersebut.

Untuk meningkatkan Disiplin dan kinerja pegawai Aparatur Sipil Negara di Kabupaten Merangin, Pemerintah Daerah Kabupaten Merangin memberikan Tambahan Penghasilan Pegawai, yang tertuang pada Peraturan Bupati Merangin Nomor 70 tentang Tambahan Penghasilan Pegawai. Selanjutnya penelitian ini juga ingin mencari bukti empiris pengaruh antara tambahan penghasilan pegawai dan disiplin Pegawai Negeri Sipil. Berdasar hal tersebut diatas kami memberi judul artikel: "Analisis Implementasi Peraturan Bupati Merangin Nomor 70 tentang Tambahan Penghasilan Pegawai dalam Meningkatkan Disiplin Aparatur Sipil Negara pada Dinas Pekerjaan Umum dan Penataan Ruang Kabupaten Merangin “

Berdasarkan uraian diatas, maka permasalahan yang akan diteliti dirumuskan sebagai berikut:

1. Bagaimana proses Implementasi Peraturan Bupati Merangin Nomor 70 Tahun 2018 ?

2. Apa saja kendala Implementasi Peraturan Bupati Merangin Nomor 70 Tahun 2018 tentang tambahan penghasilan pegawai terhadap peningkatan Disiplin ASN pada Dinas Pekerjaan Umum dan Penataan Ruang Kabupaten Merangin?

Berdasarkan identifikasi diatas, maka tujuan penelitian ini dapat dirumuskan sebagai berikut:

1. Untuk menguraikan secara empiris mengenai proses Implementasi Peraturan Bupati Merangin Nomor 70 tahun 2018.

2. Untuk menjelaskan secara empiris mengenai pengaruh Implementasi Peraturan Bupati Merangin Nomor 70 tahun 2018 tentang tambahan penghasilan pegawai terhadap peningkatan Disiplin ASN pada Dinas Pekerjaan Umum dan Penataan Ruang Kabupaten Merangin.

\section{Metode Penelitian}

Jenis penelitan yang di gunakan ini merupakan jenis penelitian kualitatif. Penelitian ini dimaksudkan untuk memberi gambaran dan menganalisa seberapa besar pengaruh Tambahan Penghasilan Pegawai (TPP) dalam meningkatkan disiplin pegawai pada Dinas Pekerjaan Umum 
dan Penataan Ruang Kabupaten Merangin Provinsi Jambi.

Penelitian ini dilakukan serta difokuskan terhadap Pegawai Negeri Sipil yang bekerja pada Dinas Pekerjaan Umum dan Penataan Ruang Kabupaten Merangin. Dalam penentuan Lokasi penelitian, Moleong (2007:132) menentukan cara terbaik untuk ditempuh dengan jalan mempertimbangkan teori substantif dan menjajaki lapangan dan mencari kesesuaian dengan kenyataan yang ada dilapangan.

Lokasi penelitian merupakan tempat dimana peneliti melakukan penelitian terutama dalam menangkap fenomena atau peristiwa yang sebenarnya terjadi. Adapun dasar pemilihan lokasi penelitian Pada Dinas Pekerjaan Umum dan Penataan Ruang merupakan OPD yang mempunyai alokasi anggaran dan Pegawai yang besar selanjutnya pegawai pada Dinas Pekerjaan Umum dan Penataan Ruang mendapatkan honorarium yang cukup besar di banding dengan pegawai dari OPD lain, dan hal ini sesuai dengan besarnya resiko pekerjaan yang terdapat pada Pekerjaan Umum dan Penataan Ruang.

Informan dalam penelitian ini adalah Pegawai Negeri Sipil Dinas Pekerjaan Umum dan Penataan Ruang Kabupaten Merangin. Informan dipilih dengan menggunakan metode Purposive Sampling, yakni informan dipilih dengan berdasarkan pengetahuan dan keabsahan informasi yang dimilikinya, berdasarkan jabatan dan pengalamannya. oleh karena itu, dalam penelitian ini peneliti menentukan informan sebanyak 10 orang.

Untuk mendapatkan data atau informasi yang dibutuhkan secara akurat dalam penelitian ini, peneliti menggunakan metode sebagai berikut:

a. Wawancara mendalam, teknik pengumpulan data dengan wawancara ini dilakukan dengan cara memberikan pertanyaan-pertanyan langsung secara lisan, tujuannya adalah untuk memperoleh data primer dari informan. Studi kepustakaan

a. Studi kepustakaan adalah teknik pengumpulan data yang relevan dengan masalah penelitian melalui buku, surat kabar, atau literature-literatur yang mendukung lainnya. Studi pustaka merupakan langkah awal dalam metode pengumpulan data. b. Dokumentasi, Menurut Arikunto (2010) dokumentasi yaitu mencari data mengenai hal-hal atau variable yang berupa catatan, transkip, buku, surat kabar, prasasti, notulen rapat, lengger, agenda dan sebagainya.

\section{HASIL DAN PEMBAHASAN}

\section{Dasar Pembentukan Organisasi}

Dinas Pekerjaan Umum dan Penataan Ruang Kabupaten Merangin dibentuk berdasarkan Peraturan Daerah Kabupaten Merangin Nomor 10 Tahun 2016 tentang Pembentukan dan Susunan Organisasi Perangkat Daerah serta Peraturan Bupati Merangin Nomor 38 Tahun 2016 tentang Kedudukan, Susunan Organisasi, Tugas Pokok dan Fungsi serta Tata Kerja Dinas Daerah. Dinas Pekerjaan Umum dan Penataan Ruang merupakan unsur Perangkat Daerah yang dipimpin oleh Kepala Dinas dalam melaksanakan tugasnya berkedudukan dibawah dan bertanggungjawab langsung kepada Bupati dan secara teknis administratif mendapatkan pembinaan dari Sekretaris Daerah.

\section{Visi dan Misi Dinas Pekerjaan Umum dan Penataan Ruang Kabupaten Merangin} a. Visi

Sesuai dengan tugas pokok dan fungsi Dinas Pekerjaan Umum dan Penataan Ruang Kabupaten Merangin dan sesuai dengan RPJMD Kabupaten Merangin, maka Visi Dinas Pekerjaan Umum dan Penataan Ruang Kabupaten Merangin ditetapkan sebagai berikut : "Infrastruktur Pelayanan Dasar yang Berkualitas menuju Merangin EMAS"

b. Misi

Selanjutnya untuk mewujudkan visi di atas, maka ditetapkan Misi Dinas Pekerjaan Umum dan Penataan Ruang Kabupaten Merangin sebagai berikut :

1. Mempercepat pembangunan infrastruktur jalan;

2. Mempercepat pembangunan infrastruktur sumberdaya air;

3. Mempercepat pembangunan infrastruktur permukiman;

4. Mempercepat pembangunan infrastruktur pekerjaan umum dan penataan ruang yang 
Analisis Pelaksanaan Peraturan Bupati Merangin Nomor 70 Tahun 2018 Tentang Tambahan Penghasilan Karyawan dalam Peningkatan Disiplin Dinas PNS di Dinas Pekerjaan Publik dan Tata Ruang Kabupaten Merangin

Farid Hidayat

berlandaskan tata ruang;

5. Meningkatkan akuntabilitas dan kinerja pelayanan Dinas Pekerjaan Umum dan Penataan Ruang.

\section{Sumber Daya Aparatur}

Jumlah Pegawai Negeri Sipil (PNS) pada SKPD Dinas Pekerjaan Umum dan Penataan Ruang Kabupaten Merangin sampai dengan 30 April 2020 sebanyak 117 (seratus tujuh belas) orang dan pegawai PTT sebanyak 142 orang, dengan rincian per Jabatan dan Per Golongan sebagai berikut:

\section{Hasil}

1. Proses Implementasi Peraturan Bupati Merangin Nomor 70 Tahun 2018.

a. Isi Kebijakan (Content of Policy) Mencakup:

Interest Affected (kepentingan yang mempengaruhi)

Interest Affected ini berkaitan dengan berbagai kepentingan yang mempengaruhi suatu implementasi kebijakan. Indikator ini berargumen bahwa suatu kebijakan dalam pelaksanaannya pasti melibatkan banyak kepentingan, dan sejauh mana kepentingankepentingan tersebut membawa pengaruh terhadap implementasinya.

\section{Type of Benefits (Tipe Manfaat)}

Pada point ini content of policy berupaya untuk menunjukkan atau menjelaskan bahwa dalam suatu kebijakan harus terdapat beberapa jenis manfaat yang menunjukkan dampak positif yang dihasilkan oleh pengimplementasian kebijakan yang hendak dilaksanakan. bahwa kebijakan pemberian TPP ini memberikan manfaat terhadap PNS diantaranya peningkatan disiplin pegawai, mendorong pegawai dalam peningkatan kinerja dan juga meningkatkan kesejahteraan pegawai.

\section{Extent of Change Envision(derajat perubahan yang ingin dicapai).}

Setiap kebijakan memiliki target yang hendak dan ingin dicapai. Content of policy yang ingin dijelaskan pada poin ini adalah bahwa kebijakan pemberian TPP ini telah dapat mengubah perilaku pegawai sesuai dengan target yang perubahan yang harapkan, target perubahan yang dimaksud dalam Peraturan Bupati Nomor 70 Tahun 2018 ini adalah memotivasi agar pegawai lebih berdisiplin, lebih meningkatkan kinerja dan dengan berdisiplin dan kinerja yang baik dapat berimbas dengan meningkatnya kesejahteraan pegawai.

Site of Decision Making (letak pengambilan keputusan).

Pengambilan keputusan dalam suatu kebijakan memegang peranan penting dalam pelaksanaan suatu kebijakan, pemberian TPP ini dinilai sangat tepat dan Pegawai dapat mengikuti aturan sesuai dengan isi Peraturan Bupati Nomor 70 Tahun 2018.

Program Implementer (pelaksana program) Dalam menjalankan suatu kebijakan didukung dengan adanya pelaksana kebijakan yang kompeten dan kapabel demi keberhasilan suatu kebijakan untuk keberhasilan kebijakan pemberian TPP ini, implementor/pelaksana kebijakan sudah terdata dengan baik, data data pegawai tersebut sudah direkam pada mesin absensi, rekaman dilakukan dalam bentuk sidik jari dan wajah,sehingga data implementor sudah terdata dengan baik.

Resources Committed (Sumber-sumber daya yang digunakan)

Pelaksanaan kebijakan harus didukung oleh sumberdaya-sumberdaya yang mendukung agar pelaksanaannya berjalan dengan baik, bahwa untuk keberhasilan kebijakan pemberian TPP ini harus mempersiapkan sumber daya yang mendukung diantaranya adalah mempersiapkan pengelola aplikasi mesin absensi, pengadaan mesin absensi dan terakhir adalah memastikan ketersediaan anggaran untuk pembayaran TPP sampai dengan bulan Desember.

b. Lingkungan Implementasi (Context of Implementation)

1. Institution and Regime Characteristic (Karakteristik lembaga dan rezim yang sedang berkuasa). Dalam suatu kebijakan perlu dipertimbangkan pula kekuatan atau kekuasaan, kepentingan serta strategi yang digunakan oleh para aktor yang terlibat guna memperlancar jalannya pelaksanaan 
suatu implementasi kebijakan. Untuk keberhasilan kebijakan pemberian TPP ini adalah memberikan informasi yang tepat kepada implementor/kctor, hal ini dipandang perlu untuk lakukan karena informasi tentang isi Peraturan Bupati nomor 70 ini mengandung aturan - aturan yang harus dipatuhi jika tidak dipatuhi maka jumlah besaran TPP PNS akan di potong.

2. Compliance and Responsiveness (Tingkat Kepatuhan dan Adanya Respon dari Pelaksana) kepatuhan implementor dan respon yang baik pada suatu kebijakan sangat berpengaruh terhadap keberhasilannya, bahwa semenjak diberlakukannya kebijakan pemberian TPP ini terlihat peningkatan kepatuhan pegawai dan respon yang baik, hal ini tergambar data dari rekapan absensi dan laporan harian pelaksanaan tugas PNS.

\section{Pengaruh TPP terhadap disiplin}

Implementasi kebijakan akan berhasil apabila para implementornya mematuhi aturan - aturan yang diberikan. Kriteria pemberian TPP adalah untuk CPNS di berikan sebesar 80\% (delapan puluh persen) dari TPP PNS, kriteria selanjutnya diambil dari aspek disiplin yaitu dari rekapitulasi kehadiran pegawai dari mesin absensi dengan bobot 60\% dan terakhir adalah PNS dan CPNS harus membuat laporan pelaksana tugas harian pegawai yang harus dibuat pegawai setiap hari dan dilaporkan pada awal bulan depan ini memiliki bobot penilaian sebesar 40\%. Selanjutnya adalah Pemotongan TPP, pemotongan dikenakan kepada pegawai yang tidak membuat laporan prestasi kerja, terlambat masuk bekerja dan/ atau tidak mengisi daftar hadir, cepat pulang dan/ atau tidak mengisi daftar hadir, tidak masuk bekerja, cuti sakit atau izin karena sakit yang tidak dirawat inap diatas 10 (sepuluh) hari, tidak mengikuti upacara kedisiplinan dan hari besar tanpa keterangan kecuali sakit, tidak menghadiri acara/kegiatan kedinasan atau resmi lainnya yang dilaksanakan oleh Pemerintah Kabupaten Merangin, dijatuhi hukuman disiplin, Pegawai yang tidak membuat laporan harian pelaksanaan tugas pegawai dikenakan pemotongan TPP berdasarkan prestasi kerja, pegawai yang terlambat masuk kerja dan/ atau tidak mengisi daftar hadir, dikenakan pemotongan TPP berdasarkan disiplin pegawai.Pegawai yang cepat pulang dan/ atau tidak mengisi daftar hadir.

Besaran potongan yang berbeda -beda pada setiap pelanggaran yang dilakukan seperti : Tidak masuk bekerja tanpa keterangan yang sah dikenakan pemotongan sebesar 5\% (lima perseratus) untuk tiap I (satu) hari tidak masuk bekerja, tidak masuk bekerja dengan keterangan yang sah dan bukan kedinasan dikenakan pemotongan sebesar $2 \%$ untuktiap satu haritidak masuk bekerja; Pegawai yang melaksanakan cuti sakit atau izin karena sakit tidak dikenakan pemotongan TPP paling lama 10 (sepuluh) hari akumulatif dalam satu bulan, dan untuk hari berikutnya dikenakan pemotongan sebesar $2 \%$ untuk tiap satu hari tidak masuk bekerja berikutnya dan Pegawai yang menjalani rawat jalan setelah selesai menjalani rawat inap untuk waktu paling lama 10 hari kerja, tidak dilakukan pemotongan TPP, dan untuk hari berikutnya dikenakan pemotongan TPP sebesar $2 \%$ untuk satu hari tidak masuk bekerja berikutnya.

\section{Kendala kendala Implementasi Peraturan Bupati Merangin Nomor 70 Tahun 2018}

Untuk kendala yang terjadi sebenarnya tidak terdapat kendala yang berarti, tetapi ada sedikit pada proses pembuatan laporan, sering terjadi laporan yang dibuat kadang ditambahtambah, hal ini tentu tidak akan terjadi apabila pengawasan dari atasan dalam pembuatan laporan ini lebih ditingkatkan lagi.

Selanjutnya kendala yang terjadi dalam implementasi kebijakan pemberian TPP ini adalahmasihterdapatoknumpegawaiyang hanya mengambil absen pagi dan sore saja, setelah itu mereka hilang atau ijin, dan selanjutnya masih minimnya sarana dan prasarana penunjang pelaksanaan kebijakan tersebut, seperti mesin absensi hanya 1 unit, selanjutnya dari sisi kinerja yang diukur adalah dari laporan pelaksana tugas harian pegawai, pada saat pembuatan laporan harian ini terdapat penyimpangan/rekayasa jenis pekerjaan yang dilakukan pegawai, ini terjadi karena kurangnya pengawasan dari atasan langsung pegawai tersebut. 
Analisis Pelaksanaan Peraturan Bupati Merangin Nomor 70 Tahun 2018 Tentang Tambahan Penghasilan Karyawan dalam Peningkatan Disiplin Dinas PNS di Dinas Pekerjaan Publik dan Tata Ruang Kabupaten Merangin

Farid Hidayat

\section{Pembahasan}

\section{Proses Implementasi Peraturan Bupati Merangin Nomor 70 Tahun 2018.}

Jika kita kaitkan proses implementasi Peraturan Bupati Nomor 80 Tahun 2018 tentang pemberian TPP dengan menggunakan teori Ripley dan Franklin, kriteria pengukuran keberhasilan implementasi menurut Ripley dan Franklin (1986) didasarkan pada tiga aspek, yaitu: (1) tingkat kepatuhan birokrasi terhadap birokrasi di atasnya atau tingkatan birokrasi sebagaimana diatur dalam undang-undang, (2) adanya kelancaran rutinitas dan tidak adanya masalah; serta (3) pelaksanaan dan dampak (manfaat) yang dikehendaki dari semua program yang ada terarah.

Analisis keberhasilan pelaksanaan implementasi Peraturan Bupati Merangin Nomor 70 Tahun 2018 tentang Tambahan Penghasilan Pegawai Negeri Sipil pada Dinas Pekerjaan Umum dan Penataan Ruang Kabupaten Merangin pada penelitian ini menggunakan Teori Ripley dan Frangklin yang menyatakan bahwa keberhasilan implementasi didasari 3 asepk, dengan pembahasan sebagai berikut :

\section{a. Tingkat kepatuhan}

Ripley dan Franklin menjelaskan variabel Kepatuhan (compliance) sebagai tingkat kepatuhan implementor dalam bertindak, apakah sesuai dengan ketentuan dan mematuhi peraturan yang ditetapkan dalam kebijakan. Tingkat keberhasilan implementasi kebijakan dapat di ukur dengan melihat tingkat kepatuhan (baik tingkat kepatuhan bawahan kepada atasan, atau kepatuhan implementor terhadap peraturan) dalam mengimplementasikan sebuah program. Kepatuhan tersebut mengacu pada perilaku implementor itu sendiri sesuai dengan standar dan prosedur serta aturan yang ditetapkan oleh kebijakan. Pada Dinas Pekerjaan Umum dan penataan Ruang terlihat tingkat kepatuhan pegawai terhadap peraturan sudah baik, peneliti melihat bahwa terjadi peningkatan kesadaran akan berdisiplin dalam bekerja. Penerapan kebijakan ini memotivasi pegawai untuk berdisiplin dan melaksanakan pekerjaan harian dengan baik dengan bukti dibuatnya laporan pelaksanaan tugas, walaupun dilapangan masih terjadi sedikit penyimpangan, tetapi secara garis besar penerapan kebijakan ini berjalan baik.

\section{b. Kelancaran Pelaksanaan Rutinitas dan fungsi Perkantoran}

Pemberian TPP pada Dinas Pekerjaan Umum dan Penataan Ruang Kabupaten Merangin telah meningkatkan semangat kerja pegawai, hal ini ditandai dengan terlihat pengaruhnya terhadap kelancaran rutinitas perkantoran dalam rangka implementasi Peraturan Bupati Merangin Nomor 70 Tahun 2018 tentang Tambahan Penghasilan Pegawai, sehingga jika dilihat dari pelaksanaan rutinitas dan fungsi tidak terdapat hambatan atau kendala yang berarti, ini berarti rutinitas dan fungsi fungsi dari setiap bidang berfungsi dengan baik.

\section{c. Terjadi peningkatan kinerja dan disiplin implementor}

Pegawai Negeri Sipil sebagai unsur utama sumber daya manusia yang merupakan abdi negara dan abdi masyarakat dituntut untuk memiliki kemampuan dan kualitas tinggi namun harus disertai dengan tingkat disiplin yang tinggi pula. Aturan penerimaan TPP sudah diatur melalui penilaian sisi kinerja dan disiplin, kedua indikator ini memiliki peranan yang sangat penting, hal ini dikarenakan TPP akan diterima tergantung pada capaian masing-masing ASN, pada tingkat disiplin kerja tinggi maka akan diperoleh kinerja pegawai yang baik.

Selanjutnya pada Dinas Pekerjaan Umum dan Penataan Ruang Kabupaten Merangin dinilai bahwa terjadi peningkatan kinerja dan disiplin yang baik, dengan disiplin diharapkan bisa menjadikan Pegawai Negeri Sipil mampu melaksanakan tugas dan pekerjaan dengan baik serta menciptakan suasana kerja yang menyenangkan, tertib dan teratur sehingga memperlancar tugas organisasi, hal ini sejalan dengan teori Ripley dan Franklin bahwa implementasi kebijakan akan berhasil jika implementornya mematuhi aturan-aturan yang diberikan.

\section{Kendala Implementasi Peraturan Bupati Merangin Nomor 70 Tahun 2018.}

Pada implementasi Peraturan Bupati Merangin Nomor 8o Tahun 2018 tak luput dari kendala-kendala dalam pelaksanaan, walaupun 
tidak terlalu signifikan, pada prakteknya dilapangan masih ada segelintir pegawai yang hanya mengejar absensi saja. Setelah absen pagi mereka meninggalkan kantor dengan berbagai ijin dan muncul lagi pada saat absensi sore. Hal selanjutnya yang menjadi kendala adalah sarana pendukung, yaitu masih minimnya mesin absensi, Dinas PUPR hanya memiliki I mesin absensi yang melayani 259 pegawai. Jika ini tidak ditambah akan menghambat kelancaran pelaksanaan kebijakan pemberian TPP ini. Berikutnya adalah mengenai kinerja, pembuatan laporan ini juga terdapat kendala diantaranya adalah isi dari laporan pelaksana tugas harian pegawai, yang isinya yaitu kegiatan/pekerjaan yang dikerjakan oleh pegawai setiap hari dan direkap dalam sebulan, yang menjadi penilai laporan ini adalah atasan langsung masing masing pegawai. Terdapat sedikit kendala pada proses pembuatan laporan yaitu sering terjadi laporan yang dibuat kadang ditambahtambah, hal ini tentu tidak akan terjadi apabila pengawasan dari atasan dalam pembuatan laporan ini lebih ditingkatkan lagi.

\section{KESIMPULAN}

DarihasilpenelitiantentangImplementasi Peraturan Bupati Merangin Nomor 70 Tahun 2018 tentang Tambahan Penghasilan Pegawai dalam rangka meningkatkan disiplin Aparatur Sipil Negara pada Dinas Pekerjaan Umum dan Penataan Ruang Kabupaten Merangin, terlihat bahwa Implementasi Pemberian Tambahan Penghasilan Pegawai pada Dinas Pekerjaan Umum dan Penataan Ruang telah berjalan dengan baik, penerapan Perbub ini telah dapat meningkatkan kedisiplinan Aparatur sipil Negara, hal ini dinilai dari aspek. Kepatuhan dalam bekerja sudah baik, selanjutnya dilihat dari aspek kedua yaitu kelancaran rutinitas dan fungsi ini masih berfungsi dengan semestinya dan kegiatan pada bidang tetap lancar. Pada aspek ketiga yaitu terlaksananya dampak (manfaat) yang dikehendaki, dalam hal ini manfaat yang dikehendaki yaitu terlihatnya peningkatan disiplin dan kinerja pegawai. Sehingga dapat disimpulkan bahwa semenjak diterapkannya pemberian TPP ini telah menunjukkan peningkatan kinerja, semangat kerja dan disiplin pegawai.

Implementasi kebijakan ini juga tidak luput dari beberapa kendala. Kendala yang dihadapi adalah kurangnya sarana dan prasana penunjang seperti mesin absensi yang dimiliki cuma ada 1 , hal ini tentu mengganggu pada saat absensi.

Selanjutnya kendala yang terjadi adalah kurangnya pengawasan atasan langsung dalam mengawasi bawahannya dalam membuat laporan harian pelaksana tugas pegawai. Dan kendala terakhir adalah ada sebagian kecil pegawai yang hanya mengambil absensi pagi dan sore saja, selanjutnya menghilang dengan berbagai alasan, dan mereka tetap membuat laporan harian pelaksana tugas seperti biasa, sehingga besaran TPP oknum tersebut sama jumlahnya dengan pegawai yang aktif bekerja.

Dengan diberlakukannya Pemberian Tambahan Penghasilan Pegawai sejak tahun 2019, peneliti memberi saran sebagai berikut :

a. Untuk kepatuhan pegawai dalam menjalankan kebijakan sudah sesuai dengan yang diharapkan, untuk itu diharapkan para pejabat yang berwenang agar dapat meningkatkan pengawasan terhadap penegakan disiplin dan juga mengawasi pembuatan Laporan pelaksana tugas pegawai,

b. Disarankan agar menjadi perhatian pemangku kebijakan di tahun yang akan datang adalah penambahan besaran jumlah TPP untuk staf, karena terlihat sangat jauh besarannya antaran pejabat eselon dengan staf, apalagi pada Dinas Pekerjaan Umum dan Penataan Ruang ini memiliki beban kerja yang berat, sehingga perlu dipertimbangkan lagi untuk meningkatkan besaran jumlah TPP nya.

\section{DAFTAR PUSTAKa}

Muchlis Hamdi, Siti Ismaryati (2016) Buku Materi Pokok MAPU5103 Metodologi Penelitian Administrasi, Universitas Terbuka.

Mutiara Sabarani Pangabean (2015) Buku Materi Pokok EKMA 5207 Manajemen Sumber Daya Manusia, Universitas Terbuka.

Muh. Irfan Islamy edisi 2 (2016) Buku Materi Pokok ADPU44 Kebijakan Publik, Universitas Terbuka.

Sugiono (2010) Metode Penelitian Kuantitatif, Kualitatif dan $R \& D$, Alfabeta, Bandung.

Budi Winarno (2012) Kebijakan Publik : Teori, Proses, dan Studi Kasus :Yogjakarta

Leo Agustino (2011) Dasar - Dasar Kebijakan Publik, Bandung : Alfabeta.

Mangkunegara, Anwar Prabu (2009) Evaluasi Kinerja 
Analisis Pelaksanaan Peraturan Bupati Merangin Nomor 70 Tahun 2018 Tentang Tambahan Penghasilan Karyawan dalam Peningkatan Disiplin Dinas PNS di Dinas Pekerjaan Publik dan Tata Ruang Kabupaten Merangin Farid Hidayat

SDM, Bandung : PT Refika Aditama.

Soekidjo Notoatmodjo (2003) Pengembangan Sumber Daya Manusia, Jakarta : Rineka Cipta

Ripley, Rendal B. and Grace A. Franklin (1986) Policy Implementation and Bureaucracy, second edition, the Dorsey Press, Chicago-Illionis

Grindle, Merilee S. (1980) Politics and Policy Implementation in The Third World, Princnton University Press, New Jersey.

Haedar Akib (2010) Implementasi Kebijakan : Apa, Mengapa dan Bagaimana. Jurnal Administrasi Publik, Volume 1 No. 1 Thn. 2010

Rachmad Hidayat, Adam Idris, dan Masjaya (2014). Implementasi Kebijakan Peraturan Pemerintah Nomor 53 Tahun 2010 Tentang Disiplin PNS Pada Kantor Kementerian Agama Kabupaten Berau . Jurnal Administrative Reform, Vol.2 No. 2,.

Khan, Alamdar H, Muhammad Aleem dan Wasim (2011) Impact of Job Statisfaction on Employee Performance : On Empirical Study Of Antonomus Medical Institutions of Pakistan. African Journal of Business Management Vol. 6 (7) pp 2697-2705.

Ali, Akbar, Maira A, Johan Zaib H, (2012) Impact Of Motivation on The Working Performance of Employees : Case study of Pakistan, Global Advanced Research Juornal of Manajemen and Business Studies, Vol 1 (4) pp. 126-133.

Prasetia, H (2012) Metode Penelitian Administrasi, Tanggerang : Universitas Terbuka.

Wibowo (2011) Manajemen Kinerja, Edisi ke 3. Jakarta :
Fajar Interpratama offset.

Yakup Tasin (2018) Implementasi kebijakan disiplin pegawai negeri sipil berdasarkan Peraturan Pemerintah Nomor 53 Tahun 2010 pada Bagian Organisasi, Sekretarian Daerah Kabupaten Malinau. Jakarta : Tugas Akhir Program Magister, Magister Administrasi Publik Universitas Terbuka.

Rita (2019) Evaluasi kebijakan pemberian tambahan perbaikan penghasilan (TPP) studi pada Sekretariat Tana Tidung. Jakarta : Tugas Akhir Program Magister, Magister Administrasi Publik Universitas Terbuka.

Achmad Azhari (2017) Kajian implementasi kebijakan pemberian tambahan penghasilan pegawai negeri sipil dan calon pegawai negeri sipil dikantor kecamatan lubuk linggau barat I, kota Lubuk Linggau. Jakarta : Tugas Akhir Program Magister, Magister Administrasi Publik Universitas Terbuka.

\section{Peraturan dan Perundang - undangan}

Undang - undang Nomor 5 tahun 2014 tentang Aparatur Sipil Negara.

Peraturan Bupati Merangin Nomor 70 tahun 2018 tentang Pemberian Tambahan Penghasilan Pegawai di Lingkungan Pemerintah Kabupaten Merangin.

Keputusan Bupati Merangin Nomor 110/BKPSDMD/2020 tentang Besaran Tambahan Penghasilan Pegawai di Lingkungan Pemerintah Kabupaten Merangin. 